\title{
Feasibility assessment of remanufacturing, repurposing, and recycling of end of vehicle application lithium-ion batteries
}

\author{
Meaghan Foster ${ }^{1}$, Paul Isely ${ }^{2}$, Charles Robert Standridge ${ }^{2}$, Md Mehedi Hasan ${ }^{2}$ \\ ${ }^{1}$ Stephen Ross CPA, St. Joseph, MI, ${ }^{2}$ Grand Valley State University (United States) \\ mfoster@stephenrosscpa.com, iselyp@.gvsu.edu, standric@.gvsu.edu, basanm@mail.gvsu.edu
}

Received: September 2013

Accepted: June 2014

\section{Abstract:}

Purpose: Lithium-ion batteries that are commonly used in electric vehicles and plug-in electric hybrid vehicles cannot be simply discarded at the end of vehicle application due to the materials of which they are composed. In addition the US Department of Energy has estimated that the cost per $\mathrm{kWh}$ of new lithium-ion batteries for vehicle applications is four times too high, creating an economic barrier to the widespread commercialization of plug-in electric vehicles. (USDOE, 2014). Thus, reducing this cost by extending the application life of these batteries appears to be necessary. Even with an extension of application life, all batteries will eventually fail to hold a charge and thus become unusable. Thus environmentally safe disposition must be accomplished.

Addressing these cost and environmental issues can be accomplished by remanufacturing end of vehicle life lithium ion batteries for return to vehicle applications as well as repurposing them for stationary applications such as energy storage systems supporting the electric grid. In addition, environmental safe, "green" disposal processes are required that include disassembly of batteries into component materials for recycling.

The hypotheses that end of vehicle application remanufacturing, repurposing, and recycling are each economic are examined. This assessment includes a forecast of the number of such batteries to ensure sufficient volume for conducting these activities. 
Design/methodology: The hypotheses that end of vehicle application remanufacturing, repurposing, and recycling are economic are addressed using cost-benefit analysis applied independently to each. Uncertainty is associated with all future costs and benefits. Data from a variety of sources are combined and reasonable assumptions are made. The robustness of the results is confirmed by sensitivity analysis regarding each key parameter.

Determining that a sufficient volume of end of vehicle application lithium-ion batteries will exist to support remanufacturing, repurposing, and recycling involves estimating a lower bound for the number of such batteries. Based on a variety of forecasts for electric vehicle and plugin hybrid electric vehicle production, a distribution of life for use in a vehicle, and the percent recoverable for further use, three projections of the number of end of vehicle applications batteries for the time period 2010 to 2050 are developed. The lower bound is then the minimum of these three forecasts. Multiple forecasts based on multiple sources of information are used to help reduce uncertainty associated with finding the lower bound, which is particularly important given the short time such vehicles have been in use.

Findings: The number of lithium-ion batteries becoming available annually for remanufacturing, recycling and repurposing is likely to exceed 3,000,000 between 2029 and 2032 as well as reaching 50\% of new vehicle demand between 2020 and 2033. Thus, a sufficient number of batteries will be available. Cost benefit analysis shows that remanufacturing is economically feasible, saving approximately $40 \%$ over new battery use. Repurposing is likewise economically feasible if research and development costs for new applications are less than $\$ 82.65$ per $\mathrm{kWh}$ for upper bound sales price of $\$ 150.00$ per $\mathrm{kWh}$. For a lower bound in R\&D expenses of $\$ 50$ per $\mathrm{kWh}$, the lowest economic sales price is $\$ 114.05$ per $\mathrm{kWh}$. Recycling becomes economically feasible only if the price of lithium salts increases to $\$ 98.60$ per $\mathrm{kg}$ due to a shortage of new lithium, which is possible but perhaps not likely, with increasing demand for lithium-ion batteries.

Research limitations/implications: The demand for lithium-ion batteries for vehicle applications through 2050 has a high degree of uncertainty. Repurposing applications are currently not fully developed and recycling processes are still evolving. There is a high degree of uncertainty associated with the cost-benefit analysis.

Practical implications: Lithium-ion batteries are a major cost component of an electric vehicle and a plug-in electric hybrid vehicle. One way of reducing this cost is to develop additional uses for such batteries at the end of vehicle application as well as an environmentally friendly method for recycling battery components as an alternative to destruction and disposal. 
Social implications: The use of lithium-ion batteries in vehicles as opposed to fossil fuels is consistent with the guiding principles of sustainability in helping to meet current needs without compromising the needs and resources of future generations. Reusing entire lithium-ion batteries or recycling the materials of which they are composed further reinforces the sustainability of the use of lithium-ion batteries.

Originality/value: The results show that a sufficient number of batteries to support remanufacturing, repurposing, and recycling will be available. Remanufacturing is shown to be economically feasible. Repurposing is shown to be feasible under reasonable conditions on design and development. Recycling will likely not be economically feasible in isolation but will eventually be necessary for all batteries. Thus, the costs of recycling must be assigned to original vehicle use, remanufacturing and repurposing applications.

Furthermore, this effort integrates information from a wide variety of sources to show the economic feasibility of end of vehicle application uses for lithium-ion batteries.

Keywords: Lithium-ion batteries, recycling, remanufacturing, repurposing, forecasting, cost-benefit analysis

\section{Introduction}

Current technology lithium-ion batteries deployed in the power train of vehicles have a designed end of vehicle application of 8 to 10 years. By lithium-ion battery we mean a collection of lithium-ion cells that work together through electrical wiring and a control board. End of vehicle application means the ability of the battery to hold a charge has fallen below regulatory standards for use in vehicles. A small percentage of the cells within the battery may have failed beyond repair.

What to do with lithium-ion batteries after the end of vehicle application is an important issue as discussed by Neubauer and Persaran (2011). A battery may be able to still hold a significant charge level and thus have additional economic value that can be reclaimed in one of three ways:

- Remanufacturing for intended reuse in vehicles. Replacement of any group with damaged cells within the battery shows promises as an effective remanufacturing strategy. A remanufacturing process is described by Schneider, Kindlein, Souza and Malfatti (2009). 
- Repurposing by reengineering a battery for a non-vehicle, stationary storage application. This usually means reconfiguring the cells comprising the battery and developing a different control system as well as repairing any damage as in remanufacturing. For example, a stationary energy storage system, connected to traditional and renewable sources, could be constructed from end of vehicle application lithium ion batteries as discussed by Andrijanovits, Hoimoja and Vinnikov (2012) as well as by Yang, Liu, Baskaran, Imhoff and Holladay (2010) and by Díaz-González (2012).

- Recycling that is disassembling each cell in the battery and safely extracting the precious metals, chemicals and other bi-products, which are sold on the commodities market if economic to do so. Processes for recycling are discussed by Paulino, Busnardo and Afonso (2008).

Each of these has the potential for lowering the life cycle cost of the battery by increasing its value following the end of vehicle application, which could in turn make an electric vehicle (EV) or plug-in hybrid electric vehicle (PHEV) a more attractive economic choice. Thus, cost-benefit analysis was used to determine the economic viability of each independently. Robustness of key parameter values was assessed.

In addition to showing the economic value potential of end of vehicle application lithium-ion batteries, it is important to show that they will exist in sufficient number to support the pursuit of remanufacturing, repurposing, and recycling applications. A lower bound can be determined from the number of batteries initially installed in EV's and PHEV's which is equal to the number of such vehicles produced. This lower bound was computed by considering various forecasts of the number of EV's and PHEV's for the period 2010-2050.

\section{Availability of End of Vehicle Application Lithium-Ion Batteries}

The number of end of vehicle application lithium-ion batteries available over time can be estimated from forecasts of the number of EV'S and PHEV's projected to be sold over time. Multiple previously existing such forecasts encompass a wide range. This is reflective of the challenges of creating a market for EV's and PHEV's and consequently the lithium-ion batteries that power them (Boston Consulting Group 2010). These multiple forecasts can be organized into three categories:

- A pessimist view such as that provided by the Energy Information Administration's (EIA) statistical analysis of future vehicle demand (EIA, 2010).

- An optimist view such as that provided by the International Energy Agency's (IEA) future EV and PHEV report. (IEA 2011). 
- A middle view such as that computed as the mathematical average of three independent industrial forecasts. These industrial forecasts seem reasonable as they are within the upper and lower bounds created by the public forecasts in items 1 and 2 .

Assumptions concerning these forecasts are as follows:

- The EIA (pessimistic view) forecast ends at 2035. No growth after 2035 was assumed.

- The demand for PHEV vehicles in 2010 is so small that it can be considered to be zero.

- The optimistic forecast is a fraction of the IEA forecast, which appears to contain an inconsistency. About 120 million in total sales per year is projected for 2050 but the report also states that $55 \%$ of that amount is just short of 120 million. Thus, this projection appears to be overestimated by nearly $50 \%$. Reducing the forecast by $50 \%$ to account for this apparent inconsistency still results in a very high upper bound. This is explained by the IEA report not accounting for full market saturation of vehicles. To adjust for this omission and obtain a usable upper bound, an additional 50\% reduction was applied resulting in an optimistic forecast of $25 \%$ of the original IEA forecast.

- Manufacturing of new EV and PHEV vehicles will be expanded to meet demand.

A Long-range Energy Alternatives Planning system (LEAP) model ("Commend, an introduction" 2012) was used to transform EV and PHEV vehicle demand forecasts into a forecast of the volume of end of vehicle application life lithium-ion batteries available for remanufacturing, recycling, and repurposing as summarized in Figure 1.

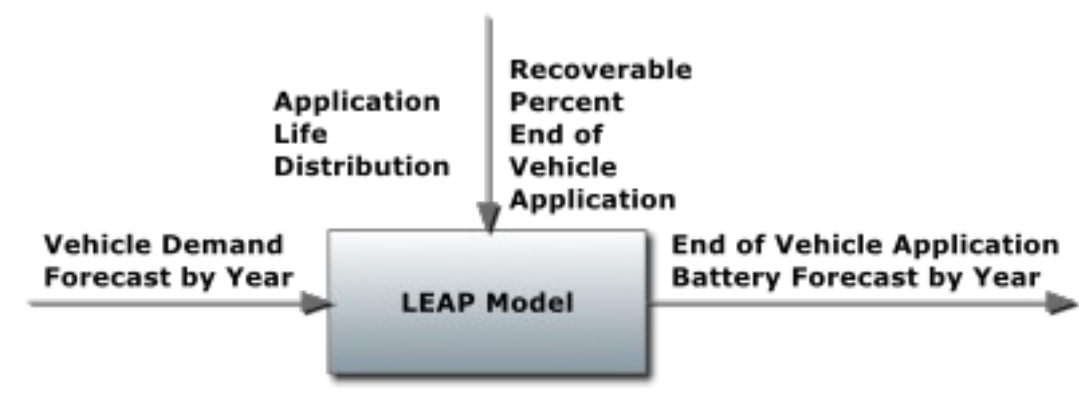

Figure 1. End of Vehicle Application Battery Forecasting Model

The model considers that $85 \%$ of the batteries are reusable at end of vehicle application life and that the remaining $15 \%$ being are damaged beyond repair (Jody, Daniels, Duranceau, Pomykala \& Spangenberger, 2010).

Battery vehicle application life is modeled as uniformly distributed between 3 and 10 years. The maximum value is based on design specifications of 8-10 years of application life (GM- 
Volt.com, 2011). Such batteries have been in use an insufficient time for experience to confirm the frequency with the maximum end of vehicle application duration can be reached. We have observed an end of life point in as little as 3 years in some cases. As no other information on battery life is currently available, modeling this quantity as uniformly distributed is appropriate as only the minimum and maximum can be estimated.

From this input, the supply of end of vehicle application lithium ion batteries available for remanufacturing, repurposing, and recycling was forecast. Results are shown for the optimistic, middle, and pessimistic vehicle demand forecasts in Figures 2, 3, and 4. In 2035, the number of available end of vehicle application batteries ranges from 1.376 million in the pessimistic forecast to 6.759 million in the optimistic forecast with a middle forecast of 3.773 million, enough batteries to justify remanufacturing, repurposing, and recycling efforts. More importantly, the number of available end of vehicle application life batteries is approximately between $55 \%$ and $60 \%$ of the number of batteries needed for new EV and PHEV production further supporting the opportunity for remanufacturing. In 2050, this range is approximately $70 \%$ to $85 \%$, showing a growing opportunity for remanufacturing.

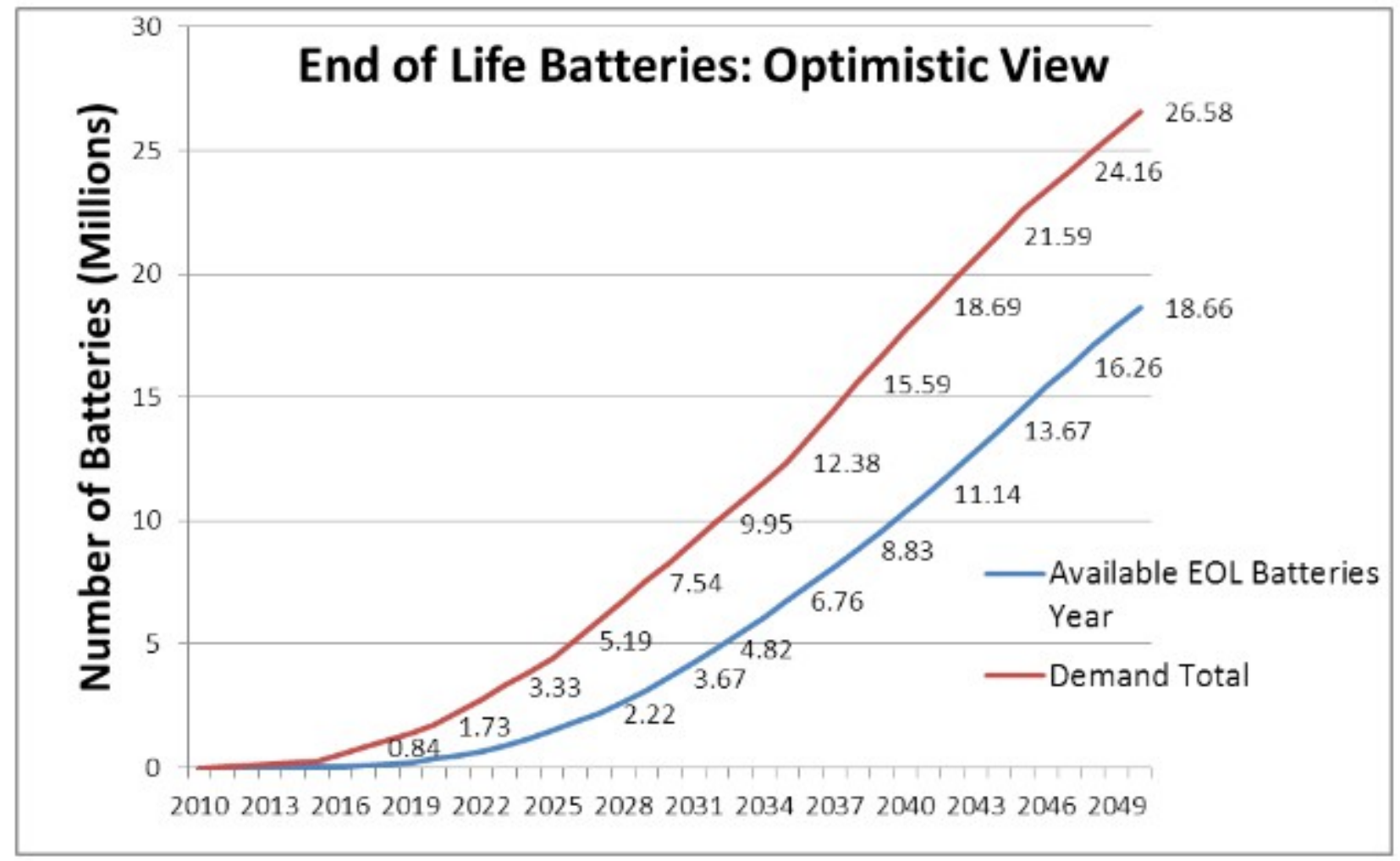

Figure 2. Optimistic View of the Number of Available End of Life Batteries Based on IEA (2011) 


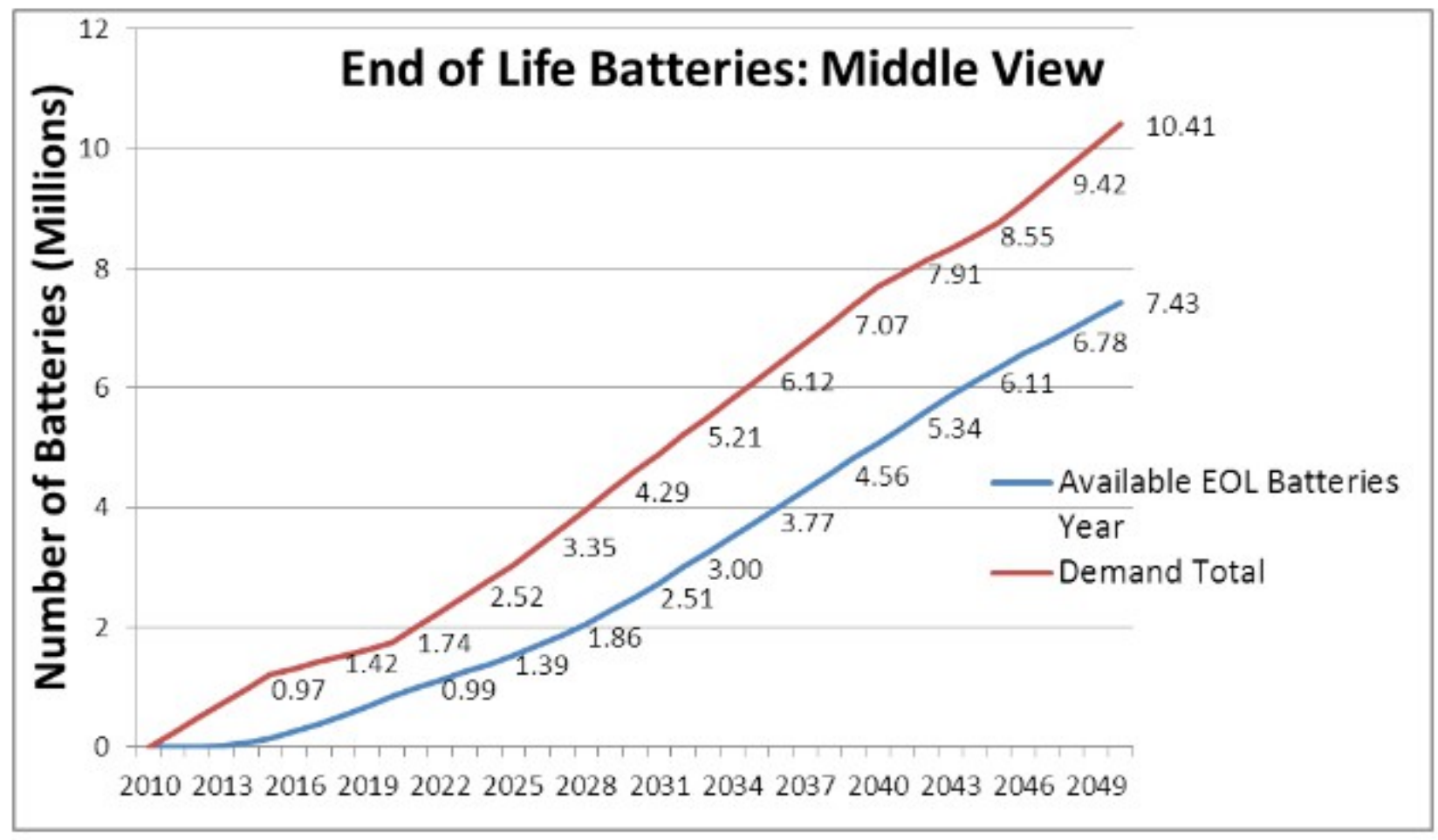

Figure 3. Middle View of the Number of Available End of Life Batteries based on Industrial Forecasts

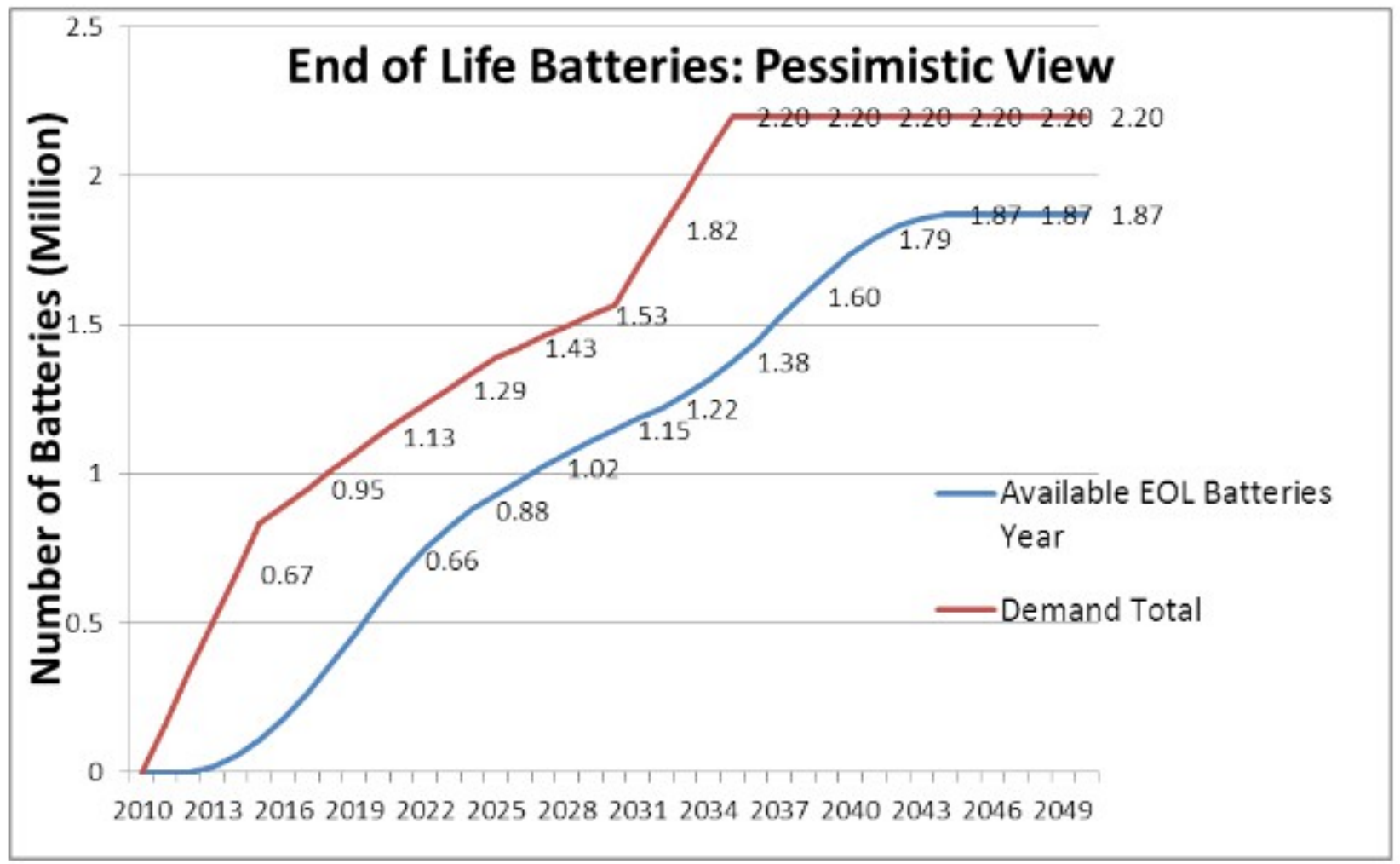

Figure 4. Pessimistic View of the Number of Available End of Life Batteries based on EIA (2010) 


\section{Cost Benefit Analysis}

There are three options for handling end of vehicle application lithium ion batteries: remanufacturing, repurposing, and recycling. The cost-benefit analysis for each is developed independently of the other two. In this, section the costs and benefits common to all three are discussed. Costs and benefits are projected over a five year period with a $3 \%$ discount rate and are expressed per individual battery. Currently, information is most available concerning the Chevrolet Volt battery. The cost of manufacturing a new Chevrolet Volt battery is estimated to be $\$ 10,000$ (Abuelsamid 2010). A report by Argonne National Laboratory Center for Transportation (Gaines \& Cuenca, 2000) provides a percentage breakdown for manufacturing cost of an EV battery: $80 \%$ material, $10 \%$ labor, with the remaining $10 \%$ being overhead which includes the research and development cost required to create after vehicle application life reprocessing systems.

Gaines and Cuenca (2000) also estimate material handling and receiving costs. The worst case scenario for remanufacturing and repurposing is $1 \%$ of the cost per battery. For recycling, which requires more material handling, the worst case scenario cost is $\$ 1$ per pound.

Transportation costs are calculated as $\$ 2.50$ per pound based on an average of estimates from hazardous material freight shipped domestically and within 1000 miles for remanufacturing and repurposing. For recycling, the cost of shipping from the automotive manufacturing center in Detroit to an established recycling center in Lancaster, Ohio can be calculated more precisely. The weight of a Chevrolet Volt battery is used which General Motors currently quotes at 435 pounds (GM-Volt.com, 2011). This nominal weight General Motors was increased to 500 pounds to account for additional packaging. Lithium ion currently is considered a Class 9 Hazardous Material with most shipping occurring via ground freight which incurs a surcharge. Fuel surcharges are included as well.

Avoided storage of end of vehicle application lithium ion batteries is a benefit. Storage cost is estimated at $\$ 20$ per square foot annually which includes lighting, environmental control and rental expenses for a 30 square foot battery. For example, the battery in the Chevrolet Volt is 5.5 feet long (GM-Volt.com, 2011). The rental cost of warehouse space varies widely with $\$ 20$ per square foot being a relatively low estimate (Curtis, 2003). Thus, the benefit of avoiding storage is conservatively estimated.

\subsection{Remanufacturing}

One way to potentially lower vehicle battery costs is to use remanufactured, instead of new, batteries. Haruna, Itoh, Horiba, Seki and Kohno (2011) discuss some advanced techniques in this regard. Remanufacturing has to do with replacing cells within a battery that can no longer 
hold sufficient charge to meet the standards for use in a vehicle. Remanufacturing involves partial disassembly of the battery, removal of substandard cells, replacement of these cells, and reassembly of the battery.

Remanufacturing avoids costs associated with producing new batteries as well as storage costs for end of vehicle life batteries through their reuse. Battery production, new or remanufactured, requires labor, material, and overhead. These costs are about $\$ 10,000$ for a new battery and are estimated to be $\$ 2,500$ for a remanufactured battery. Thus, a benefit of $\$ 7,500$ in avoided costs is realized by remanufacturing.

Labor and overhead are conservatively considered to be the same for a remanufactured battery as for a new battery. The cost savings for a remanufactured battery are related to materials. The assumption is made that $10 \%$ of the battery must be replaced. Batteries are composed of individual cells. Thus the assumption can be equivalently stated as $10 \%$ of the cells must be replaced. Our experience in handling one particular type of end of vehicle application batteries consisting of groups of 96 cells with subgroups of 8 cells indicates that at most one subgroup needs to be replaced. Thus, $10 \%$ seems to be a conservative assumption. The $80 \%$ material cost would be $\$ 8,000$ for a new battery. Since only $10 \%$ of cells are replaced, the cost for a remanufactured battery is $\$ 800$.

Currently, there is no large scale remanufacturing of end of vehicle application lithium ion batteries. Thus, the cost of facilities to conduct this activity must be assumed, based on the cost of manufacturing facilities for new batteries, and the robustness of these assumptions assessed. Martínez (2010) reports that cost of the plant for making new batteries recently built in Holland, MI by LG Chem is $\$ 303,000,000$ and is capable of producing 200,000 batteries per year. Thus the cost per first production year battery is $\$ 1515$. A cost reduction for a battery remanufacturing plant with respect to a new plant seems reasonable. The individual cell manufacturing capabilities, involving a considerable amount of chemistry and cell construction, will not be replicated. The activities of the remanufacturing plant will be limited to electrical and mechanical activities needed to dissemble batteries into cells and reassemble cells into batteries. Thus, it is assumed that remanufacturing will be carried out in a new $\$ 25,000,000$ remanufacturing plant with a 30 year payback period capable of producing 30,000 remanufactured batteries per year. The cost per first year remanufactured battery is $\$ 833$, $55 \%$ of the cost of a new battery.

The cost benefit analysis for remanufacturing is presented in Table 1 . When the Total Costs over Benefits row is negative it shows savings compared to a new battery, but when it is positive it shows a new battery is less expensive. Even after the high initial cost of investment for creating the new remanufacturing plant as well as the operational, transportation, and material handling costs discussed above, remanufacturing is a viable alternative to reduce the cost of a lithium-ion battery in a vehicle application by approximately $40 \%$. 
The robustness of the initial plant cost estimate must be examined. The initial plant investment recovery cost is less than $1 \%$ of the total cost. If this cost were 10 times higher, remanufacturing would still be economic. Thus, the assumption is robust.

\begin{tabular}{|c|c|c|c|c|c|c|}
\hline Costs & FY & FY & FY & FY & FY & \\
\hline $\begin{array}{l}\text { (Negative Values = Decreased } \\
\text { Costs) }\end{array}$ & 2012-13 & 2013-14 & 2014-15 & 2015-16 & 2016-17 & TOTAL \\
\hline A. Operational Costs ${ }^{1}$ & $\$ 2,800$ & $\$ 2,884$ & $\$ 2,971$ & $\$ 3,060$ & $\$ 3,151$ & $\$ 14,866$ \\
\hline Labor & $\$ 1,000$ & $\$ 1,030$ & $\$ 1,061$ & $\$ 1,093$ & $\$ 1,126$ & $\$ 5,309$ \\
\hline Replacement Material & $\$ 800$ & $\$ 824$ & $\$ 849$ & $\$ 874$ & $\$ 900$ & $\$ 4,247$ \\
\hline Overhead & $\$ 700$ & $\$ 721$ & $\$ 743$ & $\$ 765$ & $\$ 788$ & $\$ 3,716$ \\
\hline R+D Costs & $\$ 300$ & $\$ 309$ & $\$ 318$ & $\$ 328$ & $\$ 338$ & $\$ 1,593$ \\
\hline B. Transportation $(\$ 2.50 / \text { pound })^{2}$ & $\$ 1,250$ & $\$ 1,288$ & $\$ 1,326$ & $\$ 1,366$ & $\$ 1,407$ & $\$ 6,636$ \\
\hline C. Material Handling + Receiving ${ }^{3}$ & $\$ 100$ & $\$ 103$ & $\$ 106$ & $\$ 109$ & $\$ 113$ & $\$ 531$ \\
\hline $\begin{array}{l}\text { D. Initial Plant Investment } \\
\text { Recovery }\end{array}$ & $\$ 28$ & $\$ 29$ & $\$ 29$ & $\$ 30$ & $\$ 31$ & $\$ 147$ \\
\hline $\begin{array}{l}\text { Subtotal of Costs (Rows A } \\
\text { through D) }\end{array}$ & $\$ 4,178$ & $\$ 4,303$ & $\$ 4,432$ & $\$ 4,565$ & $\$ 4,702$ & $\$ 22,180$ \\
\hline E. Revenues / Benefits & $\$ 8,105$ & $\$ 8,048$ & $\$ 7,990$ & $\$ 7,929$ & $\$ 7,867$ & $\$ 39,939$ \\
\hline $\begin{array}{l}\text { E1. Reduction of New Battery } \\
\text { Costs }^{5}\end{array}$ & $\$ 7,500$ & $\$ 7,425$ & $\$ 7,348$ & $\$ 7,268$ & $\$ 7,186$ & $\$ 36,727$ \\
\hline $\begin{array}{l}\text { E2. Avoided Storage } \\
{\text { ( } \$ 20 / \text { square foot })^{6}}^{\text {se }}\end{array}$ & $\$ 605$ & $\$ 623$ & $\$ 642$ & $\$ 661$ & $\$ 681$ & $\$ 3,212$ \\
\hline $\begin{array}{l}\text { Total Costs over Benefits (Sum of } \\
\text { Rows A through D minus Row E) }\end{array}$ & $(\$ 3,927)$ & $(\$ 3,745)$ & $(\$ 3,557)$ & $(\$ 3,364)$ & $(\$ 3,165)$ & $(\$ 17,759)$ \\
\hline Cumulative Change & $(\$ 3,927)$ & $(\$ 7,672)$ & $(\$ 11,230)$ & $(\$ 14,594)$ & $(\$ 17,759)$ & \\
\hline
\end{tabular}

NOTES and REFERENCES:

1. Chevy Volt battery manufacturing cost of $\$ 10,000$ (Abuelsamid, 2010) with percentage rates taken from Gaines and Cuenca (2000) Labor 10\%, Overhead 7\%, R+D 3\%, and material $80 \%$. as well as $10 \%$ of existing material replaced.

2. Transportation costs are derived from estimates from hazardous material freight shipment and include a fuel surcharge and assume shipment within 1000 miles at 500 pounds which includes 435 pounds based on the Chevy Volt battery with additional package weight

3. Based on Gaines and Cuenca (2000): $1 \%$ of battery cost

4. Assume a new remanufacturing plant is installed this year at $\$ 25,000,000$ with a 30 year payback period, 30,000 battery plant production per year

5. $\$ 10,000$ cost of new Chevy Volt Battery (Abuelsamid, 2010) less labor, overhead, and material costs of a remanufacturer battery

6. $\$ 20 /$ square foot is an estimate of the cost of warehousing a battery this includes lighting, temperature control and rent (Curtis, 2003) with 30.25 square feet for a current Chevy Volt Battery

Table 1. Cost Benefit Analysis per Battery for Remanufacturing

\subsection{Repurposing}

Repurposing lithium-ion batteries after the end vehicle application provides a second way to extend useful life and thus lower the overall cost of the battery. Repurposing is a relatively new idea that currently appears most useful for stationary storage applications, which will be the focus of the cost benefit analysis. Repurposing requires dismantling batteries into cells and reassembling cells into a different configuration than for a vehicle application as well as developing the control system, both hardware and software, for the application. Each configuration may require a specifically designed battery case. Thus, each repurposing 
application appears to be unique, requiring its own design, development, and manufacturing activities.

Therefore, the analysis assumes that a $\$ 30$ million dollar plant would be built this year with a 30 year payback period and a capacity to make 5,000 units per year. Thus the cost per first production year battery is $\$ 6,000$, over seven times more per battery than remanufacturing and thus about 4 times more than the cost of manufacturing a new battery, an extremely conservative estimate which accounts for the anticipated high variability among repurposing applications.

Gaines and Cuenca (2000) estimate that research and development costs could range from $\$ 50$ to $\$ 150$ per $\mathrm{kWh}$ and that a successful storage system built from repurposed lithium-ion batteries could be sold for $\$ 50$ to $\$ 150$ dollars per kWh. For example, a Chevy Volt battery has a $16 \mathrm{kWh}$ capacity. Thus, research and development costs for this battery would range from $\$ 800$ ( $=16 \mathrm{kWh} \times \$ 50 / \mathrm{kWh}$ ) to $\$ 2,400$. Further, the same authors estimate that additional $10 \%$ in research and development costs are needed to support the addition of such a storage system to the grid. For example for a Chevy Volt battery, this cost would range from $\$ 80$ $(=\$ 800 \times 10 \%)$ to $\$ 240$. In addition, the revenue from the sale of a repurposed Chevy Volt battery would also be in the $\$ 800$ to $\$ 2400$ range.

The cost benefit analysis for the optimistic view of $\$ 50$ per $\mathrm{kWh}$ in $\mathrm{R} \& \mathrm{D}$ expenses and $\$ 150$ per $\mathrm{kWh}$ in sales is shown in Table 2 . Like remanufacturing, repurposing does have the potential to lower initial battery costs.

The initial plant investment recovery cost is conservatively estimated and can be viewed as an upper bound. Any reduction in this cost will only make remanufacturing more profitable.

Robustness with respect to $R \& D$ expenses and sales revenue can be examined as follows. Since costs and benefits are linear, it can be straightforwardly determined that the highest R\&D expense for which repurposing is profitable given $\$ 150$ per $\mathrm{kWh}$ in sales is $\$ 82.65$ per $\mathrm{kWh}$. In the same manner, given an R\&D expense of $\$ 50$ per $k W h$, the lowest sale price for which repurposing is profitable is $\$ 114.05$. This leads to equation 1 which is valid in the range ( $\$ 50.00$ to $\$ 82.65$ ) per $\mathrm{kWh}$ for R\&D expenses and thus ( $\$ 114.05$ to $\$ 150.00$ ) per $\mathrm{kWh}$ for sales revenue. Note that sales revenue must increase by about $\$ 1.10$ for each $\$ 1.00$ increase in $R \& D$ expenses.

Sales per $\mathrm{kWh}=1.10 * \mathrm{R} \& \mathrm{D}$ expenses per $\mathrm{kWh}+59.00$ 


\begin{tabular}{|c|c|c|c|c|c|c|}
\hline $\begin{array}{l}\text { Costs } \\
\text { (Negative Values = Decreased } \\
\text { Costs) }\end{array}$ & $\begin{array}{c}F Y \\
2012-13\end{array}$ & $\begin{array}{c}\text { FY } \\
2013-14\end{array}$ & $\begin{array}{c}\text { FY } \\
2014-15\end{array}$ & $\begin{array}{c}\text { FY } \\
2015-16\end{array}$ & $\begin{array}{c}F Y \\
2016-17\end{array}$ & TOTAL \\
\hline $\begin{array}{l}\text { A. Research and Development } \\
\text { Costs }^{1}\end{array}$ & $\$ 800$ & $\$ 824$ & $\$ 849$ & $\$ 874$ & $\$ 900$ & $\$ 4,247$ \\
\hline B. Transportation $(\$ 2.50 / \text { pound })^{2}$ & $\$ 1,250$ & $\$ 1,288$ & $\$ 1,326$ & $\$ 1,366$ & $\$ 1,407$ & $\$ 6,636$ \\
\hline C. Material Handling + Receiving ${ }^{3}$ & $\$ 100$ & $\$ 103$ & $\$ 106$ & $\$ 109$ & $\$ 113$ & $\$ 531$ \\
\hline D. Infrastructure Costs ${ }^{4}$ & $\$ 80$ & $\$ 82$ & $\$ 85$ & $\$ 87$ & $\$ 90$ & $\$ 425$ \\
\hline $\begin{array}{l}\text { E. Initial Plant Investment } \\
\text { Recovery }\end{array}$ & $\$ 200$ & $\$ 206$ & $\$ 212$ & $\$ 219$ & $\$ 225$ & $\$ 1,062$ \\
\hline $\begin{array}{l}\text { Subtotal of Costs ( Rows A through } \\
\text { E) }\end{array}$ & $\$ 2,430$ & $\$ 2,503$ & $\$ 2,578$ & $\$ 2,655$ & $\$ 2,735$ & $\$ 12,901$ \\
\hline F. Revenues / Benefits & $\$ 3,005$ & $\$ 3,095$ & $\$ 3,188$ & $\$ 3,284$ & $\$ 3,382$ & $\$ 15,954$ \\
\hline $\begin{array}{l}\text { F1. Secondary Market } \\
\text { Storage Sales }\end{array}$ & $\$ 2,400$ & $\$ 2,472$ & $\$ 2,546$ & $\$ 2,623$ & $\$ 2,701$ & $\$ 12,742$ \\
\hline $\begin{array}{l}\text { F2. Avoided } \\
\text { Storage( } \$ 20 / \text { square foot })^{7}\end{array}$ & $\$ 605$ & $\$ 623$ & $\$ 642$ & $\$ 661$ & $\$ 681$ & $\$ 3,212$ \\
\hline $\begin{array}{l}\text { Total Costs over Benefits } \\
\text { (Sum of Rows A through E minus } \\
\text { Row F) }\end{array}$ & $(\$ 575)$ & $(\$ 592)$ & $(\$ 610)$ & $(\$ 628)$ & $(\$ 647)$ & $(\$ 3,053)$ \\
\hline Cumulative Change & $(\$ 575)$ & $(\$ 1,167)$ & $(\$ 1,777)$ & $(\$ 2,406)$ & $(\$ 3,053)$ & \\
\hline \multicolumn{7}{|c|}{$\begin{array}{l}\text { NOTES and REFERENCES: } \\
\text { 1. Assume } \$ 50 / \mathrm{kWh} \text { R+D cost for a } 16 \mathrm{kWh} \text { Chevy Volt battery } \\
\text { 2. Transportation costs are derived from estimates from hazardous material freight shipment and include a fuel } \\
\text { surcharge and assume shipment within } 1000 \text { miles at } 500 \text { pounds which includes } 435 \text { pounds based on the Chevy } \\
\text { Volt battery with additional package weight } \\
\text { 3. Based on Gaines and Cuenca ( } 2000): 1 \% \text { of battery cost } \\
\text { 4. Based on Gaines and Cuenca }(2000) \text { report assuming } 10 \% \text { of } \mathrm{R}+\mathrm{D} \text { costs to build capacity into grid } \\
\text { 5. Assume a new repurposing plant is installed this year at } \$ 30,000,000 \text { with a } 30 \text { year payback period, } 5,000 \\
\text { battery plant production per year } \\
\text { 6. Assume } \$ 150 / \mathrm{kWh} \text { secondary market sales at } 16 \mathrm{kWh} \text { for Chevy Volt battery } \\
\text { 7. } \$ 20 / \text { square foot is an estimate of the cost of warehousing a battery this includes lighting, temperature control } \\
\text { and rent (Curtis, } 2003 \text { ) with } 30.25 \text { square feet for a current Chevy Volt Battery }\end{array}$} \\
\hline
\end{tabular}

Table 2. Cost Benefit Analysis per Battery for Repurposing ( $R$ \& D Cost $=\$ 50 \mathrm{kWh}$ )

\subsection{Recycling}

Eventually, each cell in every battery will be unable to support any application and thus must be recycled. Recycling has to do with dissembling a cell into its components and properly disposing of each component. Jody et al. (2010) estimated that with increased technological breakthroughs recycling could yield up to $20 \%$ recovery of battery cost. Some technical aspects of recycling are discussed by Georgi-Maschler, Friedrich, Weyhe, Heegn and Rutz (2012). A review of recycling processes is given by $\mathrm{Xu}$, Thomas, Francis, Lum, Wang and Liang (2008). Kumar (2010) takes the position that recycling is necessary to ensure an adequate supply of lithium. It should be noted that there are non-monetary benefits of lithium ion battery recycling in regards to environmentalism and sustainability (DeWulf et al., 2010).

Gaines \& Cuenca (2000) estimate the operational costs of a lithium ion battery recycling facility at $\$ 2.25$ per pound. For a Chevy Volt battery, this yields an operational cost of recycling of $\$ 979$ ( $=\$ 2.25 /$ per pound $* 435$ pounds). As lithium-ion battery recycling facilities currently exist, no plant infrastructure charges are assumed. This is a conservative assumption. 
The benefits of recycling come from two areas, the recoverable commodities extracted from the battery during the actual recycling process and the avoided costs for storing end of vehicle application batteries. Extractable materials fall into four categories; Cobalt, Lithium salts (carbonate), aluminum and others: steel, plastic, paper and miscellaneous metals. Benefits are derived from the following sources:

- Cobalt: $\$ 16.01$ per pound on the London Metal Exchange average for 2011 (Shedd, 2013)

- Lithium salts: $\$ 6,750$ per metric ton in China in 2012 for battery grade lithium salts (Jaskula, 2013)

- Aluminum: Average $\$ 1.01$ per pound for 2012 on the US Market (Bray, 2013)

- Others: Fall 2012 commodities market prices

An optimistic assumption of $100 \%$ extraction of each of these materials was used.

The results show that in the current commodities market the costs far outweigh the benefits of recycling electric vehicle batteries as shown in Table 3.

Consider the following recycling alternatives. Lithium ion is a nonrenewable ore. The lithium used in an electric vehicle is not the pure form of lithium, instead it undergoes a series of chemical processes that turn it into what is known as lithium carbonate or more commonly lithium salts. Yet there is growing speculation that lithium supplies could soon become exhausted especially with ever increasing demand for technologies that require the mineral. If that happens, the commodity price for not only pure lithium but lithium salts could soar (Egbue and Long 2012). Gruber, Medina, Keoleian, Kesler, Everson and Wallington (2010) report a detailed study of the future supply of lithium.

Assume that lithium supplies are becoming depleted, which means they reach a minimum. Gaines and Nelson (2010) estimated in this case lithium prices could increase by 10 times their current amount. Further they state that if lithium supplies reach their capacity, meaning that all lithium supplies are exhausted that lithium prices would increase by 20 times their current amount. It is assumed the under these conditions, the price of lithium salts would increase by the same proportion. This seems reasonable as lithium salts were traded at in fall 2012 at nearly the same price as pure lithium. In a later paper (Gaines \& Nelson, 2011), the same authors argue that the latter is not likely to occur. Using the data in Table 3, recycling would be profitable if the price of lithium salts increased to $\$ 98.60 / \mathrm{kg}$, an increase of about 20 times.

In addition, suppose economies of scale can be applied to recycling as the number of batteries available for recycling increases. Since the data in Table 3 are linear, it is straightforward to determine that a $58.4 \%$ reduction in all costs $(A-C)$, would make recycling profitable. 


\begin{tabular}{|c|c|c|c|c|c|c|}
\hline $\begin{array}{l}\text { Costs } \\
\text { (Negative Values = Decreased } \\
\text { Costs) }\end{array}$ & $\begin{array}{c}F Y \\
2012-13\end{array}$ & $\begin{array}{c}\text { FY } \\
2013-14\end{array}$ & $\begin{array}{c}\text { FY } \\
2014-15\end{array}$ & $\begin{array}{c}\text { FY } \\
2015-16\end{array}$ & $\begin{array}{c}\text { FY } \\
2016-17\end{array}$ & TOTAL \\
\hline $\begin{array}{l}\text { A. Operational Costs (Assume } \\
\$ 2.25 / / \mathrm{lb} \text { at } 435 \mathrm{lbs}^{1} \text { ) }\end{array}$ & $\$ 979$ & $\$ 1,008$ & $\$ 1,038$ & $\$ 1,070$ & $\$ 1,102$ & $\$ 5,196$ \\
\hline B. Transportation ${ }^{2}$ & $\$ 1,278$ & $\$ 1,317$ & $\$ 1,356$ & $\$ 1,397$ & $\$ 1,439$ & $\$ 6,787$ \\
\hline $\begin{array}{l}\text { Class } 250 \text { freight weight } 500 \\
\text { lbs }^{3}\end{array}$ & $\$ 1,105$ & $\$ 1,138$ & $\$ 1,172$ & $\$ 1,207$ & $\$ 1,243$ & $\$ 5,865$ \\
\hline Fuel Surcharges & $\$ 141$ & $\$ 146$ & $\$ 150$ & $\$ 155$ & $\$ 159$ & $\$ 751$ \\
\hline $\begin{array}{l}\text { Hazardous Material Class } 9 \\
\text { charges }\end{array}$ & $\$ 32$ & $\$ 33$ & $\$ 34$ & $\$ 35$ & $\$ 36$ & $\$ 171$ \\
\hline $\begin{array}{l}\text { C. Material Handling + Receiving } \\
\left(\$ 1 / \mathrm{lb} \text {. for } 500 \mathrm{lb} .^{4}\right)\end{array}$ & $\$ 500$ & $\$ 515$ & $\$ 530$ & $\$ 546$ & $\$ 563$ & $\$ 2,655$ \\
\hline $\begin{array}{l}\text { Subtotal of Costs ( Rows A through } \\
\text { C) }\end{array}$ & $\$ 2,757$ & $\$ 2,840$ & $\$ 2,925$ & $\$ 3,013$ & $\$ 3,103$ & $\$ 14,638$ \\
\hline D. Revenues / Benefits & $\$ 1,146$ & $\$ 1,180$ & $\$ 1,216$ & $\$ 1,252$ & $\$ 1,290$ & $\$ 6,084$ \\
\hline D1. Recoverable Commodities & $\$ 541$ & $\$ 557$ & $\$ 574$ & $\$ 591$ & $\$ 609$ & $\$ 2,872$ \\
\hline Cobalt $(\$ 3.53 / 100 \text { grams })^{5}$ & $\$ 185$ & $\$ 190$ & $\$ 196$ & $\$ 202$ & $\$ 208$ & $\$ 980$ \\
\hline Lithium Salts $(\$ 6.75 / \mathrm{kg})^{6}$ & $\$ 118$ & $\$ 122$ & $\$ 126$ & $\$ 129$ & $\$ 133$ & $\$ 629$ \\
\hline Aluminum $(\$ 2.23 / \mathrm{kg})^{7}$ & $\$ 118$ & $\$ 122$ & $\$ 125$ & $\$ 129$ & $\$ 133$ & $\$ 626$ \\
\hline $\begin{array}{l}\text { Other (Stainless Steel, } \\
\text { Plastic, Paper, other } \\
\text { metals) }\end{array}$ & $\$ 120$ & $\$ 124$ & $\$ 127$ & $\$ 131$ & $\$ 135$ & $\$ 637$ \\
\hline $\begin{array}{l}\text { D2. Avoided Storage ( } \$ 20 / \text { square } \\
\text { foot) }{ }^{9}\end{array}$ & $\$ 605$ & $\$ 623$ & $\$ 642$ & $\$ 661$ & $\$ 681$ & $\$ 3,212$ \\
\hline $\begin{array}{l}\text { Total Costs over Benefits (Sum of } \\
\text { Rows A through C minus Row D) }\end{array}$ & $\$ 1,611$ & $\$ 1,659$ & $\$ 1,709$ & $\$ 1,761$ & $\$ 1,813$ & $\$ 8,554$ \\
\hline Cumulative Change & $\$ 1,611$ & $\$ 3,271$ & $\$ 4,980$ & $\$ 6,740$ & $\$ 8,554$ & \\
\hline \multicolumn{7}{|c|}{$\begin{array}{l}\text { NOTES and REFERENCES: } \\
\text { 1. } 435 \text { pounds represents the current weight of a Chevy Volt battery and the operation costs of } \$ 2.25 \text { per pound is } \\
\text { an estimate of operational costs for a lithium ion battery recycling facility (Gaines } \& \text { Cuenca, } 2000 \text { ) } \\
\text { 2. Transportation estimates are quoted from United Postal Service large freight and hazardous materials division } \\
\text { and assume movement of Chevy Volt batteries from Detroit Facility to Lancaster Ohio the closest large lithium ion } \\
\text { battery recycling facility } \\
\text { 3. } 500 \text { pounds is the } 435 \text { pounds that is the current weight of a Chevy Volt battery and additional weight for } \\
\text { packaging } \\
\text { 4. Material Handling is quoted at } \$ 1.00 \text { per pound based on an estimate by Gaines and Cuenca (2000) and the } 500 \\
\text { pounds is the shipping weight of the battery } \\
5 \text {. Based on Shedd ( } 2013): \$ 16.01 \text { per pound on the London Metal Exchange average for } 2011 \\
\text { 6. Based on Jaskula ( } 2013): \$ 6,750 \text { per metric ton in China in } 2012 \text { for battery grade lithium salts } \\
\text { 7. Based on Bray ( } 2013): \text { Average } \$ 1.01 \text { per pound for } 2012 \text { on the US Market } \\
\text { 8. Based on fall } 2012 \text { commodity prices for each item } \\
\text { 9. } \$ 20 / \text { square foot is an estimate of the cost of warehousing a battery this includes lighting, temperature control } \\
\text { taken from Curtis (2003) and rent with } 30.25 \text { square feet for a current Chevy Volt Battery }\end{array}$} \\
\hline
\end{tabular}

Table 3. Cost Benefit Analysis per Battery for Recycling - Fall 2012 Commodity Prices

\section{Conclusion}

The feasibility of remanufacturing, repurposing, and recycling of end of vehicle application lithium-ion batteries depends both on the availability of such batteries in sufficient number and whether the processes, including the capital investments needed to support them are economic.

There are a variety of demand forecasts for EV's and PHEV's which were classified into three types: pessimistic, optimistic, and middle. For each type, the number of end of vehicle application batteries can be derived. The results showed a sufficient supply of such batteries, estimated to reach 1,000,000 per year between 2022 and 2027 depending on the forecast. 
Expressed as a percent of new car production, the number of end of vehicle life batteries is forecast to reach $50 \%$ between 2020 and 2033. Thus, it can be concluded that a sufficient supply of end of vehicle life batteries to support remanufacturing, repurposing, and recycling will exist.

Cost benefit analysis showed that a vehicle application remanufactured battery could be produced for about $60 \%$ of the cost of a new battery using reasonable and conservative assumptions about capital costs for equipment and factory facilities to support the remanufacturing process. Applications for repurposed batteries are currently less well defined than for remanufacturing. Thus research and development expenses are a primary component of cost. It was shown that under conservative assumptions for other costs, that repurposing is economic for approximately $\$ 82.65$ per $\mathrm{kWh}$ in research and development costs, well within the range for such costs previously estimated in the literature. In addition, for a lower bound in R\&D expenses of $\$ 50$ per $k W h$, the lowest economic sales price is shown to be $\$ 114.05$ per $\mathrm{kWh}$ also well within the sale price range stated in the literature. Disassembly of individual cells for recycling was determined to not be economic unless the market price for lithium salts increases about twentyfold to $\$ 98.60$ per $\mathrm{kg}$, which some believe is possible due to demand outstripping current supply of this metal. Because recycling is required as eventually each cell in each battery will no longer be usable in any application, it is clear that original, remanufacturing, and repurposing applications will likely need to bear some recycling expenses.

\section{References}

Abuelsamid, S. (2010). General Motors builds first Volt battery pack on production line. Retrieved February 12, 2014, from http://green.autoblog.com/2010/01/07/general-motors-builds-first-voltbattery-pack-on-production-line/

Andrijanovits, A., Hoimoja, H., \& Vinnikov, D. (2012). Comparative review of long-term energy storage technologies for renewable energy systems. Electronics, 2(118), 21.

BCG-The Boston Consulting Group. (2010). Batteries for electric cars: challenges, opportunities, and the outlook to 2020. BCG Focus. Retrieved August 31, 2013, from http://www.bcg.com/expertise_impact/industries/energy_environment/publicationdetails.aspx?id=tcm:1236622\& mid=tcm:12-36569

Bray, E. L. (2013). 2012 minerals yearbook: aluminum. U.S. Department of the Interior, U.S. Geological Survey. Retrieved March 27, 2013, from

http://minerals.er.usgs.gov/minerals/pubs/commodity/aluminum/myb1-2012-alumi.pdf 
Commend, an introduction to leap. (2012). Retrieved August 31, 2013 from http://www.energycommunity.org

Curtis, D. (September 2003). The value of climate control: What it means-inside self storage. Retrieved August 31, 2013, from http://www.insideselfstorage.com/articles/2003/09/the-value-of-climatecontrol.aspx

Dewulf, J., et al. (2010). Recycling rechargeable lithium ion batteries: Critical analysis of natural resource savings. Resources, Conservation and Recycling, 54(4), 229. http://dx.doi.org/10.1016/j.resconrec.2009.08.004

Díaz-González, F. (2012). A review of energy storage technologies for wind power. Renewable \& Sustainable Energy Reviews, 16(4), 2154. http://dx.doi.org/10.1016/j.rser.2012.01.029

Egbue, O., \& Long, S. (2012). Barriers to widespread adoption of electric vehicles: An analysis of consumer attitudes and perceptions. Energy Policy, 48, 717-729. http://dx.doi.org/10.1016/j.enpol.2012.06.009

Gaines, L., \& Cuenca, R. (May 2000). Costs of lithium-ion batteries for vehicles. Center for Transportation Research, Argonne National Laboratory Publication. Retrieved August 31, 2013, from http://www.transportation.anl.gov/pdfs/TA/149.pdf.

Gaines, L., \& Nelson P. (2010). Lithium-ion batteries: possible materials issues. Center for Transportation Research, Argonne National Laboratory Publication. Retrieved August 31, 2013, from http://www.transportation.anl.gov/pdfs/B/583.PDF

Gaines, L., \& Nelson, P. (2011). Lithium-ion batteries: Examining material demand and recycling issues. Report by: Argonne National Laboratory, Argonne, IL. Retrieved August 31, 2013, from: www.transportation.anl.gov/pdfs/B/626.PDF

Georgi-Maschler, T., Friedrich, B., Weyhe, R., Heegn, H., \& Rutz, M. (2012). Development of a recycling process for Li-ion batteries. Journal of Power Sources, 207, 173. http://dx.doi.org/10.1016/j.jpowsour.2012.01.152

GM-Volt.com. (2011). Chevy Volt Specs. Retrieved August 31, 2013, from http://gm-volt.com/fullspecifications

Gruber, P.W., Medina, P.A., Keoleian, G.A., Kesler, S.E., Everson, M.P., \& Wallington, T.J. (2011). Global lithium availability. Journal of Industrial Ecology, 15(5), 760-775. http://dx.doi.org/ $10.1111 / \mathrm{j} .1530-9290.2011 .00359 . x$

Haruna, H., Itoh, S., Horiba, T., Seki, E., \& Kohno, K. (2011). Large-format lithium-ion batteries for electric power storage. Journal of Power Sources, 196(16), 7002. http://dx.doi.org/10.1016/j.jpowsour.2010.10.045 
International Energy Agency (IEA). (June 2011). Technology roadmap: electric and plug-in hybrid electric vehicles. Retrieved August 31, 2013, from

http://www.iea.org/publications/freepublications/publication/name,3851,en.html

Jaskula, B.W. (2013). 2012 minerals yearbook: lithium. U.S. Department of the Interior, U.S. Geological Survey. Retrieved March 27, 2013, from

http://minerals.er.usgs.gov/minerals/pubs/commodity/lithium/myb1-2012-lithi.pdf

Jody, B.J., Daniels, E.J., Duranceau, C.M., Pomykala Jr., J.A., \& Spangenberger, J.S. (September 2010). End-of-life vehicle recycling: State of the art of resource recovery from shredder residue. Center for Transporation Research, Argonne National Laboratory Publication. Retrieved August 31, 2013, from

http://www.es.anl.gov/Energy_systems/CRADA_Team/publications/End\%20of\%20life\%20vehicle\%20recycling \%20Technology\%20review.pdf

Kumar, A. (2010). Second Life and Recycling of EV Batteries Will Ensure the Completion of 'Green Car' Tag. Automotive and Transportation. Retrieved August 31, 2013, from http://www.frost.com/sublib/display-market-insight-top.do?id=216476073

Martínez, S. (2010). LG Chem to build \$303 million lithium battery plant in Holland for Chevrolet Volts. Retrieved August 31, 2013, from http://www.mlive.com/business/westmichigan/index.ssf/2010/03/lg_chem_to_build_1st_north_ame.html

Neubauer, J., \& Persaran, A. (2011). The ability of battery second use strategies to impact plug-in electric vehicle prices and serve utility energy storage applications. Journal of Power Sources, 196(23), 10351. http://dx.doi.org/10.1016/j.jpowsour.2011.06.053

Paulino, J.F., Busnardo, N.G., \& Afonso, J.C. (2008). Recovery of valuable elements from spent Li-batteries. Journal of Hazardous Materials, 150(3), 843.

http://dx.doi.org/10.1016/j.jhazmat.2007.10.048

Schneider, E.L., Kindlein, W., Souza, S., \& Malfatti, C.F. (2009). Assessment and reuse of secondary batteries cells. Journal of Power Sources, 189(2), 1264.

http://dx.doi.org/10.1016/j.jpowsour.2008.12.154

Shedd, K.B. (2013). 2011 minerals yearbook: cobalt. U.S. Department of the Interior, U.S. Geological Survey. Retrieved March 27, 2013, from

http://minerals.er.usgs.gov/minerals/pubs/commodity/cobalt/myb1-2011-cobal.pdf

U.S. Department of Energy (USDOE). (2014). Vehicle technologies incubator: Funding opportunity announcement number: DE-FOA-0000988. Retrieved February 12, 2014, from http://www.floridaenergy.ufl.edu/wp-content/uploads/DE-FOA-0000988.pdf

U.S. Energy Information Administration (EIA). (2010). Future vehicle demand 2010 data tables. 
Xu, J., Thomas, H.R., Francis, R.W., Lum, K.R., Wang, J., \& Liang, B. (2008). A review of processes and technologies for the recycling of lithium-ion secondary batteries. Journal of Power Sources, 177(2), 512. http://dx.doi.org/10.1016/j.jpowsour.2007.11.074

Yang, Z., Liu, J., Baskaran, S., Imhoff, C.H., \& Holladay, J.D. (2010). Enabling renewable energy-and the future grid-with advanced electricity storage. JOM, 62(9), 14-23. http://dx.doi.org/10.1007/s11837-010-0129-0

Journal of Industrial Engineering and Management, 2014 (www.jiem.org)

(a)

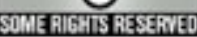

Article's contents are provided on a Attribution-Non Commercial 3.0 Creative commons license. Readers are allowed to copy, distribute and communicate article's contents, provided the author's and Journal of Industrial Engineering and Management's names are included. It must not be used for commercial purposes. To see the complete license contents, please visit http://creativecommons.org/licenses/by-nc/3.0/. 